The role of theory in the

business/management PhD: How

students may use theory to make an

original contribution to knowledge

\title{
Wilkins, S
}

http://hdl.handle.net/10026.1/14912

10.1016/j.ijme.2019.100316

The International Journal of Management Education

Elsevier

All content in PEARL is protected by copyright law. Author manuscripts are made available in accordance with publisher policies. Please cite only the published version using the details provided on the item record or document. In the absence of an open licence (e.g. Creative Commons), permissions for further reuse of content should be sought from the publisher or author. 


\title{
The role of theory in the Business/Management PhD: How students may use theory to make an original contribution to knowledge Stephen Wilkins, Selina Neri, Jonathan Lean
}

\begin{abstract}
This research investigates how $\mathrm{PhD}$ students learn about theory. The paper offers guidance on how theory may be selected and used by students, and the steps that students may take to achieve the goal of making an original contribution with their research. The data used in this study came from an online questionnaire survey completed by 62 individuals who teach and/or supervise/advise $\mathrm{PhD}$ students in business schools. The job titles of participants included Professor, Head of Department, and Director of PhD Programme. Our survey participants reported that high proportions of PhD students struggle to understand the role of theory in their research; how to create a theoretical framework/model; and how to make a theoretical contribution with their research. A majority of the survey participants agreed that students need more teaching on theory and that it is the responsibility of business schools to determine the structure, content and delivery of $\mathrm{PhD}$ programmes. Schools must also provide the necessary resources, including academic staff and learning materials. The paper concludes with sets of recommendations for $\mathrm{PhD}$ students, educators, and business schools.
\end{abstract}

Keywords:

$\mathrm{PhD}$, Doctoral education, Management research, Research training, Theory, Theoretical contribution

\section{Introduction}

In most countries, the research degree Doctor of Philosophy ( $\mathrm{PhD}$ or DPhil) is the highest academic qualification awarded by universities. Increasingly, a $\mathrm{PhD}$ is the basic requirement for an academic career in higher education (Austin, 2002). All PhDs require the candidate to undertake a major piece of independent research that makes an original contribution to knowledge, evidenced in a thesis (referred to as a dissertation in the United States), which is reviewed and examined by academics (Park, 2005). The requirements to complete a PhD vary greatly between countries, universities and even subjects. Some programmes involve only research but, increasingly, the trend internationally is to have a taught component that is formally assessed before the candidate conducts independent research. For example, in the United Kingdom (UK), the Economic \& Social Research Council (ESRC), which is the key public provider of funding for PhDs in Business/Management, generally expects candidates to begin their doctoral study with a Master in Research degree (MRes), or an equivalent qualification (known as the 1+3 model, with the numbers representing the number of years spent in the taught and research stages).

The $\mathrm{PhD}$ is a demanding qualification that requires students to demonstrate expert knowledge and a variety of skills and attributes, such as creativity and analytical ability (Lean, 2012). Many students struggle to understand the requirements and expectations of a $\mathrm{PhD}$ and/or how to actually satisfy these requirements and expectations. In the UK, about $20 \%$ of the students that 
enrol in a PhD programme never complete it (Jump, 2013). In most countries, there are graduate schools with $\mathrm{PhD}$ completion rates considerably below 50\% (Kyvik \& Olsen, 2014; Litalien \& Guay, 2015; Spronken-Smith, Cameron, \& Quigg, 2018).

Students may quit $\mathrm{PhD}$ programmes for a variety of reasons including family obligations, financial difficulties, or simply because they receive an attractive job offer. Sometimes, the student's decision to quit is the result of insufficient motivation or the unexpected realisation of the demands of undertaking doctoral-level research. Structured doctoral programmes that have a formally taught and assessed component have been found to have a positive influence on programme graduation rates, and taught courses/modules appear to be particularly effective when there are clear learning outcomes and when the students have to submit work by specified deadlines (Geven, Skopek, \& Triventi, 2018).

Academic staff often cite students' lack of understanding of theory and theory building as common problems in $\mathrm{PhD}$ programmes (Byron \& Thatcher, 2016; Lings, 2008). Thus, this study seeks to offer guidance on how theory and theoretical concepts/perspectives may be selected and used by students, and the steps that students may take to achieve the goal of making an original contribution with their research. Specifically, this research seeks to answer the following research questions:

(1) To what extent is theory formally taught in Business/Management $\mathrm{PhD}$ programmes, and, if it is taught, how it is taught?

(2) What should Business/Management PhD students know and do in relation to theory in order to complete their programme successfully?

(3) What advice may be offered to students, educators and business schools to improve the quality of students' $\mathrm{PhD}$ theses/dissertations; programme completion times; and drop-out rates?

The research involved collecting information on the practices of business schools globally, based on the insights and experiences of academic staff who teach and/or supervise/advise $\mathrm{PhD}$ students. The findings and advice offered in this paper may be useful for various stakeholders in the doctoral education process, including educators designing or delivering doctoral courses/modules that involve theory. Students in Business/Management PhD programmes can also benefit from this study, as it may help them to better understand the requirements and expectations of $\mathrm{PhD}$ research.

This study is concerned only with the use of theory in PhD programmes. Although Saunders et al. (2015) argue that demonstrating the relevance of theory to practice is an essential component of all professional doctorates, including the Doctor of Business Administration (DBA), in $\mathrm{PhD}$ research, the focus is on theoretical issues, while in professional doctorates the emphasis is on addressing practical issues (O'Connor, 2011). Theory has a different role, and is used in different ways, in $\mathrm{PhD}$ and DBA research. Therefore, some of the commentary, arguments and recommendations offered in this article may not apply to professional doctorates.

The following five sections discuss the theoretical grounding for this study; possible definitions of theory; how theory relates to inductive, deductive and abductive research approaches; the role of theory in developing theoretical and conceptual frameworks; and how students may improve their understanding of how to make an original contribution to knowledge. Then, the study's method is explained and the results presented. The paper concludes with a 
summary and analysis of the key findings, and sets of recommendations are provided for students, educators and business schools.

\section{Theoretical grounding for study}

The theoretical grounding for the study is not straightforward as there are increasingly divergent views about the purpose and role of the PhD in society (Mowbray \& Halse, 2010; Wellington, 2013). Doctoral education may be understood as a function of the development of new knowledge and knowledge-making practices to support social and economic development in a knowledge economy context. More broadly, human capital theory may explain the expansion of doctoral level education in many areas of the world. Governments and business leaders have called on universities to improve the employability skills of doctoral students, and many business schools have responded by incorporating skills training into programmes so that graduates can contribute to national economic development (Meek, Teichler, \& Kearney, 2009).

Researchers and writers have considered the many expectations of $\mathrm{PhD}$ graduates in terms of knowledge, competencies and personal dispositions, but rarely, if ever, does theory feature in such discussion (Nyquist, 2002). Prøitz and Wittek (2019) observe that new types of doctoral education, such as the DBA, are offered by many business schools as the solution to societal challenges and call for more practice-oriented programmes. These researchers found that although the new doctoral programmes may aim to bring theory and practice closer together, there is generally no expectation that theory will be developed or advanced, which is a common goal of $\mathrm{PhD}$ research.

Human capital theory may suggest that doctoral education serves a functional purpose as a tool in the learning environment, which supports the development of utilitarian competencies in knowledge societies, whereas an idealistic approach regards research as a process of edification that understands academic education as participation in research (Simons \& Elen, 2007). Supporters of general education or edification through participation in research are upholding the Humboldtian tradition of the university, which emphasises the unity of research and education. Simons and Elen (2007) argue that it is a difficult intellectual challenge to frame the Humboldtian 'project' of enlightenment with the current 'project' to organise competency-based higher education for optimal employability.

Business schools and educators in doctoral programmes typically assume that students are aiming for an academic career. As a result, doctoral students are often regarded as apprentices that contribute to the research output and overall performance of their university (Enders, 2002). Business schools generally enjoy superior reputations, positions in rankings and research funding when their academic staff and doctoral students publish in the 'top' management journals. These journals tend to favour research that provides theoretical rather than practical or vocational contributions. In pursuit of improved rankings and funding, institutions are more likely to uphold the Humboldtian model of the university rather than newer conceptualisations favouring skills and employability competences. Thus, this research is grounded in the assumption that the purpose of PhD study aligns with the Humboldtian tradition of primarily preparing students for an academic career in a research university.

\section{What is theory?}


Corley and Gioia (2011, p. 12) define theory as "a statement of concepts and their interrelationships that shows how and/or why a phenomenon occurs." In the simplest terms, theory may be regarded as a set of interrelated concepts or ideas that explain some aspect of the real world (Lee \& Lings, 2008). Hunt (1983) specifies three criteria for recognising theory: (1) the systematically related criterion; (2) the generalisation criterion; and (3) the empirically testable criterion, while Whetten (1989) argues that theory contains four essential elements: (1) What - the factors in the theory; (2) How - how the factors are related; (3) Why - why the factors are related; and (4) Who, where, when - which represent the boundary conditions. A model is a representation of a theory, which is generally shown in graphical or mathematical form.

Creswell and Creswell (2018) suggest a three-level typology of theories. At the top of the pyramid, grand theories provide an abstract and general theoretical perspective that can influence how individuals think about the world. Giddens' structuration theory (1984) is an example of a grand theory as it attempts to bridge the gulf between structure and agency in social life. However, grand theories are too abstract to be tested empirically. The middle range theories, such as some of the general theories on human motivation, are more likely to frame empirical enquiry but are less likely to influence how individuals think about the world. Researchers are often concerned with substantive theories, at the base of the pyramid, which are specific to a particular population, problem or research setting. It is often difficult to make generalisations from substantive theories.

Theory is necessary and useful in most business and management research, and it is essential in $\mathrm{PhD}$ research. Examiners expect to see propositions and hypotheses supported by theory or theoretical concepts/perspectives, and for empirical findings to be explained by theory or theoretical concepts/perspectives. However, PhD students are often confused about the meaning of theory. Referring to general dictionaries will not help students, as the word 'theory' has a different meaning in everyday use. However, even in scientific usage, the word 'theory' has several meanings depending on the context of its use. The word is used differently by researchers in different subject disciplines, and individuals may interpret theory differently according to the philosophical viewpoint they favour (Lings, 2008).

Most business and management research aims to explain a particular behaviour, such as a choice or an outcome that is associated with individuals (e.g. leaders, employees and consumers), groups (e.g. work teams, companies and countries) or systems (e.g. company practices and government policies). Theories are used to explain such behaviour. For example, theories may be used to explain why some companies are successful while others are not, or why individual $a$ decides to buy product $x$ while individual $b$ decides to buy product $y$. Theories can be used to provide both predictions and explanations. Theories do this by specifying how different concepts or phenomena relate to one another and why these concepts or phenomena relate to each other in the way that they do.

Predictions are often stated as propositions in qualitative studies and as hypotheses in quantitative studies. Lings (2008) explains that a proposition is simply a statement that predicts a relationship between two or more concepts and constructs, whereas a hypothesis is a statement that predicts what the researcher expects to observe in the real world through empirical research. The term 'empirical research' refers to the study of reality, where only knowledge gained through observation is acceptable. A hypothesis is not itself a theory; it is simply a prediction. However, it is essential that every hypothesis is supported by theoretical arguments and logic, 
as well as previous empirical findings where they exist. Furthermore, qualitative research enquiry essentially occurs in the field, with actors and events happening in their natural settings (Denzin \& Lincoln, 2005).

According to Creswell and Creswell (2018), the hallmark of qualitative research includes the researcher as the key to data collection, focus on participants' meanings, interpretative enquiry, a holistic account and the use of theoretical lenses. The issue of generalisability in qualitative research is debated, with a difference being drawn between statistical generalisation, typical of quantitative studies where an inference is made from the sample to the population of reference, and analytical generalisation, or generalisable lessons learned or findings from qualitative studies (Eisenhardt, 1989; Eisenhardt \& Graeber, 2007; Flick, 2014).

Joas and Knobl (2009) argue that every generalisation is already a theory and that every theory can be understood as a generalisation; likewise, that a theory is never free of assumptions or empirical observations, and empirical observations should always be explained by theory or theoretical statements. For business and management researchers, theory may be regarded as a logical model or framework that describes and explains how related phenomena behave, which can be empirically tested to allow for possible falsification. According to Popper (2002), theory is always provisional and a researcher in the social sciences (as opposed to the natural sciences) can never claim to have proven a theory because a future study could always generate contradictory observations.

\section{Inductive, deductive and abductive research}

The relationships between theory and reality in the research process are illustrated in Fig. 1. Fig. 1 indicates that theory can inform reality, or vice versa, reality can inform theory. Making an original contribution to knowledge very often incorporates a theoretical contribution. There are three different research approaches by which this can be done, namely inductive, deductive and abductive. Inductive research is concerned with theory building. When there is a lack of existing theory that predicts and explains a particular behaviour in the social world, the student may collect data in the real world with the aim of building new theory. Deductive research is more suitable in situations when theory or theoretical concepts/perspectives already exist to explain specific behaviours in the social world. In such situations, the student formulates hypotheses with which to test the existing theory, with the aim of modifying the existing theory, in order to improve its predictive and explanatory powers. Sometimes, researchers encounter empirical phenomena that existing theory cannot account for. Abductive research adopts a pragmatist perspective to overcome weaknesses in the inductive and deductive approaches. Using an abductive approach, the researcher moves back and forth between the real and theoretical worlds in order to select the best explanation from competing explanations or interpretations of the data (Bell, Bryman, \& Harley, 2018).

\section{INSERT FIG. 1 HERE}

A theory should be generalisable; in other words, it should apply in a range of specified contexts and settings. For example, a particular theory of firm investment may apply in developed nations but it might not apply in developing nations. Thus, a student may attempt to 
modify the model so that it has predictive and explanatory powers in developing nations. In this example, the contribution to knowledge is not in applying the existing theory in a new context but the adaptation of the existing theory so that it can be used in the new context. Replication studies are usually insufficient for a $\mathrm{PhD}$; it is not enough for a student to only test an existing theory, as new knowledge must be generated (the original contribution). This can actually be achieved in many different ways. For example, a student may study a particular topic using a methodology that has not been previously used, which could lead to new knowledge and theoretical insights.

It is important that students explain and justify their chosen research approach in terms of their research philosophy. Ontology is concerned with the nature of reality while epistemology is concerned with what is acceptable as knowledge in a particular discipline. Inductive research generally uses a subjectivist ontology and an interpretivist epistemology. In contrast, deductive research is more often associated with an objectivist ontology and a positivist epistemology. Lin (1988) argues that qualitative studies can encompass both interpretivist and positivist traditions. It is important for students to consider their research philosophy as this shapes the assumptions about the way in which they view the world and it impacts on the way in which they conduct their research and interpret their findings (Bell, Bryman, \& Harley, 2018).

Existing theoretical concepts/perspectives are needed to provide a foundation for every research project, regardless of whether it is inductive or deductive in nature. This does not mean that the student has to 'follow' an existing theory. In inductive research, it is possible that the researcher aims to create an entirely new theory. For example, grounded theory is an example of an inductive method where theory generation results from the empirical data, without any reference to theory at the start of the research process. Creating a new theory is a highly complex and risky task that many academics consider too demanding an undertaking for $\mathrm{PhD}$ students (Lings, 2008; Phillips \& Pugh, 2015). For this reason, it is relatively rare for students to have the objective of creating a completely new theory. A more realistic goal is to identify the limits of previously proposed generalisations with the aim of making modifications that improve the predictive and explanatory power of existing theories.

\section{Theoretical and conceptual frameworks}

Whenever possible, PhD students should ground their research in existing theory. However, students often struggle to find and select relevant theories that may be useful in their research. Students also need to appreciate that simply including a number of theories in their thesis/dissertation is not the same as providing a strong theoretical foundation for their research. Theory should be used to explain the relationships between different phenomena, and the research should have some degree of theoretical coherence linking the various concepts together. General theories are often used to provide a foundation for research, which then informs the use of more specific theory that may provide superior explanatory power. Very often, students introduce new ideas or variables to an existing theory that somehow improves the theory. For example, an existing theory may be modified by incorporating ideas from a theory in another field, but there must be a logical rationale for doing this that is explained by the student. By improving an existing theory, the student can make the expected contribution to knowledge, which should already be well thought through in the student's research proposal. 
In their thesis/dissertation, most students present a theoretical framework that provides a general representation of relationships between things in a given phenomenon. The theoretical framework specifies the theory that has guided the student in their research, which helps determine what the student will measure and what relationships will be investigated. It serves as the structure and support for the rationale for the research, the problem statement, the purpose, the significance, and the research questions of the study. The theoretical framework is typically presented in the thesis/dissertation after the literature review, as it is based on existing theory that is found in the literature. A theoretical framework may be regarded as the researcher's lens with which to view the world. The student's choice of framework should reflect important personal beliefs and understanding about the nature of knowledge and how it exists, which is also related to the methodological choices made. Without a theoretical framework, the structure and vision for a study is unclear, but Iqbal (2007) claims that the creation of a theoretical framework is one of the most difficult tasks facing students in their PhD study.

Concepts are the building blocks of theory and represent the points around which business and management research is conducted. Examples include training, employee involvement, leadership style, employee loyalty and employee performance. It is usually appropriate for students to present a conceptual framework in their thesis/dissertation. A conceptual framework indicates the concepts of interest in a study and the assumed relationships between them. The conceptual framework provides a visual display of how concepts or ideas in a study relate to one another within the theoretical framework. So, while a theoretical framework is derived from theory, a conceptual framework is derived from concepts. In explaining a particular phenomenon, two researchers may each draw upon the same theory but create two different conceptual models.

Fig. 2 provides a 'use-case' illustration of the use of a theoretical and conceptual framework within the field of management education. Following this, Table 1 offers a summary of definitions and examples related to research philosophy, theoretical and conceptual frameworks, methodology and research design.

\section{INSERT FIG. 2 HERE (contained in a text box)}

\section{INSERT TABLE 1 HERE}

\section{Making an original contribution to knowledge}

$\mathrm{A} \mathrm{PhD}$ must always make an original contribution to knowledge, although the notion of originality has been debated since the $19^{\text {th }}$ century and the question of what constitutes knowledge has occupied the world's greatest thinkers since Plato. For the purpose of this study, we define originality in terms of "the essential tension between accepted prior knowledge and new discoveries or ideas" (Clarke \& Lunt, 2014, p. 804); knowledge as "that which is known" (Grant, 1996, p. 111); and new knowledge as "discoveries about phenomena that were not known previously" (McFayden \& Cannella, 2004, p. 735). Such contributions can be made in several different ways. $\mathrm{PhD}$ research can be exploratory, theory testing or problem-solving in nature (Phillips \& Pugh, 2015). Given that the PhD is essentially a qualification in research training that acts as a licence to teach in a university, Phillips and Pugh (2015) argue that the theory 
testing approach to research is most likely to lead to achievement of the $\mathrm{PhD}$ within a reasonable time period. Research that is based on theory testing may be easier for students to cope with because there is already theory and literature in the topic area, along with established norms for empirical work and data analysis in the disciplinary field.

Problem-solving research that focuses on tackling a problem in the real world, such as how organisations can improve their knowledge management or their level of innovation, or how they can make their supply chains more efficient, is usually better suited to the applied or professional doctorate, such as the $\mathrm{DBA}$, rather than the $\mathrm{PhD}$, which has a theoretical focus. This is not to say that the findings of a $\mathrm{PhD}$ will not benefit employees, managers, organisations, consumers, or societies in general. A good $\mathrm{PhD}$ will result in both theoretical and practical knowledge that often leads to recommendations for specific actors. Good theory is, in fact, practical because it advances knowledge in a discipline, guides research toward important questions, and provides useful insights for managers and organisations (Van de Ven, 1989).

This study aims to discover how PhD students learn about and apply theory in their research. Despite the multitude of articles and books on the topic of what theory is, for doctoral students the information is and remains suspended 'in the air' unless management theory is introduced as the solid block upon which the rest can stand. In this way, we can link and transition from why theory is important, what knowledge and explanations of theory exist, and whether and how theory is taught in $\mathrm{PhD}$ programmes. As explained in the following section, we do this by obtaining the views and experiences of academic staff that deliver $\mathrm{PhD}$ programmes and supervise/advise students.

\section{Method}

Given that this study is concerned with understanding the role of theory in Business/Management PhD studies and how students may select and use theory to make an original contribution to knowledge, and given the explorative nature of the research questions outlined in our introduction, an interpretivist, qualitative approach appears most suited to this investigation. The data used in this study came from an online questionnaire survey that was completed by individuals with a specific responsibility for research in business schools. The job titles of participants included Head of Department, Postgraduate Research Coordinator, Director of PhD Programme, Professor, Reader, Associate Professor and Senior Lecturer. The survey questions were developed by the authors, based on the arguments and previous empirical findings identified in the literature.

The questionnaire had 10 questions, which were intended to gain information on: whether theory is formally taught and assessed in $\mathrm{PhD}$ courses/modules in their university; the extent to which students cope or struggle with the concept of theory and the need to make an original, and possibly theoretical, contribution in their research; the theories that all business/management $\mathrm{PhD}$ students should know; and the theories that may be particularly useful or interesting in different sub-disciplines. In order to establish face and content validity, the draft questionnaire was shared with four professors that teach and supervise in a $\mathrm{PhD}$ business management programme at a leading doctoral school in the United Arab Emirates. These test participants did not report any issues that needed revision of the survey instrument.

The questionnaire was prepared using SurveyGizmo software and it consisted of both closed and open questions that were designed to gain information about the survey participants' 
experiences, actions, opinions and attitudes, without influencing the content of their answers. Examples of questions include:

- In your own words, how would you define 'theory' to a PhD student?

- Are there any new theories/theoretical concepts in your specific discipline area that may be regarded as cutting-edge, which could be recommended to students for possible use in their research?

- What advice do you have for students, to help improve their understanding of the role and purpose of theory in their research, and how they can make a theoretical contribution?

- What advice do you have for professors/supervisors/advisors, to improve how they teach and inform students about theory?

- What advice do you have for business schools, to improve how they teach students about theory? E.g. how this knowledge is delivered and student understanding is assessed.

Given that this research is concerned only with $\mathrm{PhD}$ study, a purposive sampling strategy was adopted, which involved recruiting only individuals who have experience of $\mathrm{PhD}$ programme leadership, teaching and/or supervision. Potential survey participants were identified mainly through institution websites, but the chain referral method (snowballing) was also used, whereby existing survey participants suggested to the authors the names of other possible participants. Each participant confirmed that they taught and/or supervised/advised students in a $\mathrm{PhD}$ programme.

Some 634 questionnaires were emailed to suitable individuals (with a reminder sent after about one week and a second after about two weeks), and eventually 62 complete and usable responses were returned, resulting in an overall response rate of $9.8 \%$. To estimate when data saturation was achieved, returned questionnaires were regularly monitored as they were received. After about 40 responses, the researchers perceived that they were close to saturation as the observed answers became increasingly similar to those provided by earlier participants. However, in an attempt to achieve broader discipline and geographical coverage, further responses were encouraged by continuing to send reminders. Table 2 provides a summary profile of the study's participants.

\section{INSERT TABLE 2 HERE}

\section{Results}

\subsection{Data analysis}

The data were analysed using a process of thematic analysis. This method enabled the researchers to systematically identify and organise patterns of meaning - the themes - across the data set (Braun \& Clarke, 2012). By focusing on meaning across the data set, it was possible to identify and make sense of the participants' shared attitudes, beliefs and experiences. Three researchers were involved in the data analysis by individually reading the questionnaire responses in order to familiarise themselves with the data and to form their own interpretations. Two of the researchers checked the codes and agreed the themes that were proposed by the lead researcher. 
Coding was undertaken manually. Manual coding has the advantage of allowing researchers to 'get closer to the data', to more easily identify common responses and themes. The data were coded, matching words and phrases to identify concepts that could be categorised into themes. The themes were then grouped according to whether they represented advice for students, educators or institutions. Inductive thematic saturation (Saunders et al., 2018) appeared to occur within the first fifty responses, as few new insights or views were observed in subsequent responses. In other words, no new themes were created after the first fifty responses had been analysed.

The data were finally organised in a structure comprising three levels, as suggested by Corley and Gioia (2004). At the top, are the aggregate dimensions represented by the three user groups (students, educators and business schools), then come the themes that relate to each dimension, and finally the concepts that represent meanings - attitudes, beliefs and experiences - expressed by the survey participants. The resulting data structure is presented in Table 3, which shows sample concepts and themes for each of the aggregate dimensions.

\section{INSERT TABLE 3 HERE}

\subsection{Definitions of theory}

Before students can use theory in their research, they must understand what theory is. When we asked the survey participants how they would define 'theory' to a PhD student, we received a wide variety of responses. It is clear that how theory is viewed and defined varies across both subject disciplines and individuals within disciplines. Some of the definitions offered by participants were quite broad or general, for example:

Theory is a vision of the world. (Professor, HEC Paris)

In the context of business and management, theory may be defined as sets of ideas to explain social behaviour in organisations. (Professor, University of Cambridge)

Other definitions referred to theory as a model of reality, or they focused on the explanatory and predictive aspects of theory, for example:

A theory is a conceptual framework or model of reality. (Lecturer, University of Plymouth)

Theory explains why a phenomenon exists, for example, why A, B, C happens, so that you can anticipate and predict it happening again. (Professor, University of Michigan)

Theory is a causal argument or prediction that can be tested with empirical data and tools. (Professor, Massachusetts Institute of Technology)

One participant observed that there are several competing conceptions of theory: 
I don't think that there is a single definition of theory, rather there are several competing conceptions of theory, including theory as analysis; theory as explanation; theory as prediction; and theory as prescription. $\mathrm{PhD}$ students should understand the differences between these and the assumptions on which they are based. (Reader, anonymous)

What appears evident from the responses received is that, within the context of a traditional supervisory model, $\mathrm{PhD}$ students are likely to be introduced to theory in different ways, dependent on the particular perspective of their supervisor/advisor. This suggests a potential role for taught elements within doctoral programmes to provide students with a rounded view of theory and to ensure a more consistent understanding of its nature and importance within the research process. However, it should also be recognised that learning within a doctoral programme is not developed purely through formal interactions with supervisors and lecturers. Understanding is not achieved only through a linear didactic process of dissemination whereby knowledge is passed from teacher to learner. Within a PhD programme, much learning occurs through a wide range of interactions with other doctoral students, academics and practictioners, including networking at seminars, symposia and conferences. In other words, doctoral level learning is typically comprised of elements that are both linear (transmissive, didactic and teacher-centred) and non-linear or socially constructed (Vygotsky, 1978; Kember, 1997).

\subsection{Teaching and learning in Business/Management PhD programmes}

Most $\mathrm{PhD}$ programmes in the United States (US) have a taught component, i.e., courses that must be completed by students before they embark upon their independent research. In the past, most $\mathrm{PhD}$ programmes in the UK did not have a taught component, but in recent years they have become more common. Some $68.8 \%$ of our survey participants reported that all business/management a PhD programmes in their institution have a taught component; $12.5 \%$ reported that some programmes have a taught component; while $18.7 \%$ stated that $\mathrm{PhD}$ programmes in their institution do not have a mandatory taught component.

In our survey institutions, $18.8 \%$ have a stand-alone course or module specifically on theory; $12.5 \%$ include theory as one topic in a research method course or module; and $15.6 \%$ integrate theory in the teaching of a specific business/management topic. In $42.2 \%$ of the institutions, students are expected to learn about theory through independent learning, with the support of their supervisor/advisor. Within our sample, notable differences were observed, particularly between the UK and US institutions. While $64.7 \%$ of the US institutions have a stand-alone course or module specifically on theory and $23.5 \%$ integrate theory in other courses/modules, $69.4 \%$ of the UK institutions rely on independent learning. These figures suggest that although UK institutions have begun to offer more taught courses in their doctoral programmes, theory is still a topic that commands less attention. No differences across subject disciplines were identified.

Some $42.8 \%$ of our survey participants reported that the majority of $\mathrm{PhD}$ students struggle to understand the role of theory in their research; 50.8\% reported that the majority of students struggle to create a theoretical framework/model; and $49.2 \%$ reported that students struggle to understand how to make a theoretical contribution with their research. It is apparent therefore 
that a large proportion of students find aspects of theory challenging and would benefit from more advice and guidance with regard to the role and use of theory in their research.

In view of the figures quoted in the previous paragraph, our survey participants unanimously agreed that it is essential that students should be able to define theory; understand the role of theory in business/management research; recognise a range of business/management theories through reading and analysing journal articles; understand how theory is used in creating theoretical and conceptual frameworks and models; and understand how to make a theoretical contribution. As such, these may be regarded as the essential learning outcomes in any course that includes theory as a topic.

\subsection{Exposing PhD students to business/management theories}

Some $61.2 \%$ of the survey participants favoured a more structured way for students to learn about theory, both as taught courses/modules and as a regular topic in seminars. Interestingly, this group of participants consisted of more senior academics (76.3\% were full professors), possibly indicating that appreciation of the importance of theory deepens with years of professional experience. It is possible that these participants favoured a structured approach to learning because they perceive that independent learning does not work well in practice or because the task at hand is simply too complex for students to navigate with less guidance. This group of participants believe that students should be exposed to both general management and discipline specific theories, and that students should be formally taught how to search for and read/interpret/analyse theory papers. This suggests that reading scholarly papers is in itself a craft that needs to be learned at the outset of the doctoral journey, to facilitate its assimilation into the toolkit that students can rely upon for their own development into scientific researchers. Hence, whilst respondents emphased a need for formal linear teaching, the end goal is to support non-linear learning of a more socially constructed nature.

Most business management disciplines have a large number of theories. Students in any discipline benefit from awareness of these theories, both the old, well-used ones and the new ones, which may be still relatively unknown or unproven. Some theories are commonly used in a number of different disciplines and therefore could be considered suitable for teaching to all business management PhD students as a general introduction to theory. Survey participants were asked which theories or theoretical concepts/perspectives they thought could be included in a course taught to an entire cohort of business management PhD students. To help the participants, a list of possible theories and theoretical concepts/perspectives was provided, which was based on a similar list used by the European Management Journal in its online submission system for authors. Table 4 shows the most popular choices among our survey participants.

\section{INSERT TABLE 4 HERE}

The importance afforded to Critical Theory is perhaps a reflection of its strong alignment to aspects of research philosophy, ontology and epistemology within much business and management research. Its influence within the discipline makes it an obvious contender for inclusion in introductory taught components on theory. While the other theories rated as 
important are arguably less overarching in nature, several transcend subject boundaries and might therefore have applicability for students undertaking a wide range of research studies.

Interestingly, a small number of participants objected to this question, for example:

The provided list is a mess that conflates very different notions of theory, e.g. RBV (resource based view) and institutional theory are examples of organisational theory, while interpretative 'theory' is not a theory.... The question implies that theory selection is a shopping list, rather than emerging from the research topic, philosophy, custom and practice in the subject area. I do not consider that this survey can provide any meaningful insight on teaching theory to business/management students because it presupposes a particular, debatable, conception of theory. Your findings will therefore be an artefact of these presuppositions. (Reader, anonymous)

I have deliberately not answered this question because I believe it is the wrong question. I would never presume to list what theories students should be exposed to. (Reader, University of Plymouth)

In response to these criticisms, we would highlight that several top-tier business management journals and scholarly organisations, including the Academy of Management, use similar 'mixed' lists of theories and theoretical concepts/perspectives as a means by which authors can classify their work for journal and conference submissions. If an ability to situate studies in relation to key existing theories is considered important within the business and management research community, a pre-requisite must be understanding such theories. More importantly, the findings of this study show that many $\mathrm{PhD}$ students struggle to understand what theory is and how they may use theory in their research. The implication is that programmes of research training for $\mathrm{PhD}$ students should include learning about theory, and in order to effectively study theory it makes sense for students to examine particular theories or theoretical concepts and how they can be used to underpin $\mathrm{PhD}$ level research.

If students have good awareness of the range of theories that may be useful in their research, they can make and justify rational choices and decisions. Such an approach is not intended to be prescriptive or limiting, but rather to place students in a stronger position to recognise theories that might play an important role in their research. Students may well liken the process of identifying suitable theories to 'hunting for a needle in a haystack' and therefore students may be grateful to educators who suggest where they could start with their search of the literature within their subject domain. Pedagogically, adopting a more transparent approach that makes the challenge of selecting an appropriate theoretical foundation for a given study less daunting may bring benefits in terms of achieving expected learning outcomes. Further, it may facilitate more timely completion of $\mathrm{PhDs}$ and reduce drop-out rates.

In the survey, participants were also asked to identify some of the newer or more cutting-edge theories in their discipline areas, as this could provide useful information for both educators and students. Surprisingly, in response to this question there was not a single theory that was mentioned by two or more participants. Hence, we conclude that either there is a lack of new theory across business management disciplines, or that educators are not aware of the new theory 
that does exist, or that there is simply a lack of consensus about what represents a new and potentially useful theory.

\subsection{Advice for students}

The survey participants provided a number of insights and observations to advise $\mathrm{PhD}$ students on the role of theory. An understanding of the 'real-world' context of research and the role of theory in addressing research problems was a key consideration for some.

Theory is often seen as something beyond everyday existence and unimportant for people's daily lives. However, students should recognise that theory provides a means by which individuals may consider the difficulties they face on a day to day basis or understanding other individual, social or political problems. Theory allows generalisation and through synthesising the theoretical and the practical, understanding or comprehension of the world/reality is enhanced. (Professor, University of Plymouth)

The survey participants universally agreed that students need to fully understand the literature in their $\mathrm{PhD}$ area and how their study builds on the extant theory. Students must also understand how theory is conceptualised within their field and the assumptions on which these conceptualisations are based so that they can make informed choices of the types of theories they may draw on in their research and hence how they may make a contribution. Students should investigate what has been studied before and compare different theories to identify gaps.

Students should not start working with theory until they have a clear understanding of the phenomenon they are studying. When they know what happening they wish to explain, they may then use existing theory or create new theory to explain that phenomenon. (Professor, University of Michigan)

Students must understand why they want to conduct the research, why theory is important for the research, and how they can identify a gap in current research or literature so as to know what new contribution they can make to both theory-building and managerial practices. (Professor, Monash University)

Read, read, and then read some more. Focus on the top ranked journals, key books and seminal pieces. (Emeritus Professor, University of Plymouth)

'Wide reading' was the most common and most strongly emphasised piece of advice offered for students. A student that is unwilling to read widely will rarely make a good $\mathrm{PhD}$ candidate as a great proportion of the knowledge needed to complete a $\mathrm{PhD}$ thesis/dissertation will result from reading. In particular, the survey participants advised students to consult the top-tier business management journals. These journals are more likely to have articles that specify the theory used and the theoretical contribution of the research. 
Read relevant three and four star papers [refers to the journal list of the Chartered Association of Business Schools], to see how theories have been developed and applied. (Senior Lecturer, University of Hertfordshire)

Read articles on what theory is, what it is not [possibly referring to Sutton \& Staw's classic article named 'What theory is not'], how it differs from a literature review, and how to apply it to develop hypotheses. (Endowed Chair, University of Denver)

Read the leading journals in your field, particularly the 'in press' articles [also known as 'online before print'], which are available as soon as they are accepted. Make a particular point of reading the Academy of Management Annals, as it is a great way of getting on top of the literature in a given area and the papers usually contain suggestions for future research. (Professor, University of Cambridge)

Some participants pointed out that business management research is often cross-disciplinary and thus students may need to read the literature in several different discipline areas. A number of survey participants observed the reluctance of some students to engage with numbers. It is useful for students to recognise that even if they don't intend to use a quantitative research design, they still need to have some understanding of quantitative research, because in all disciplines some research may use statistics or quantitative analysis, and if students do not understand this, they will be unable to interpret or evaluate potentially relevant research findings and implications.

Combining or borrowing theories from other disciplines can often be effectively adapted within management contexts. (Professor, University of Liverpool)

Students should have the courage to formalise arguments mathematically. If they can't do this, then very often they will be unable to think or test effectively. (Professor, Columbia University)

Although independent reading is essential for success in a $\mathrm{PhD}$ programme, one participant stressed that students should also regularly interact with their supervisors/advisors (for both advice and feedback) and that they need to sometimes 'get off campus'. This social constructivist perspective underlines the fact that doctoral education and learning about theory cannot be delivered purely through formal, linear teaching methods.

Students should attend conferences and workshops, where they can interact with and listen to high profile people in their field. (Professor, University of Cambridge)

In summary, participants reinforced the central role of theory and reading, both wide and deep, and also underlined the importance of active participation in all of the opportunities that academic life offers, such as seminars, conferences and workshops. The range of sources of learning about theory, including established scholars and peers, was a key theme emerging from 
the data. This again underlines the importance of achieving a balance between linear and nonlinear approaches to learning in doctoral education.

\subsection{Advice for educators}

Responses from the survey suggest that educators should not make assumptions about what students know. The variations in understanding observed indicate that they should customise the support they offer to an individual according to the student's specific needs. However, there are a number of activities that students may be asked to perform that are likely to be beneficial regardless of a student's topic and pre-understanding of theory and research. Responses to the survey suggest that students must not only be taught about what theory is (and isn't), but how to actually use and develop it. Furthermore, there are activities that may be undertaken by supervisors/educators that are likely to benefit students.

I think the error we often make is to assume that our students understand theory, when many do not. We could provide clearer guidance early on during supervision to ensure students think about theoretical positioning at an early stage of their studies. (Lecturer, University of Exeter)

Ask students to develop a literature review based on current issues in the last five years in top journals in their field, which should include the theories used by authors. (Senior Lecturer, University of Lincoln)

Don't be dogmatic. Encourage students to theorise and get them to explain and give examples. However, not all students will be theorists and that is okay as there are other ways to contribute to the field. (Professor, Massachusetts Institute of Technology)

While $\mathrm{PhD}$ students are working on their theses/dissertations, they should be encouraged to publish in top tier journals, which will help them understand the importance of theories and the way to claim their contributions to theory-building. (Professor, Monash University)

Build a bank of, and teach, core theories that may be used by students to inform their study. (Professor, University of Plymouth)

$\mathrm{PhD}$ supervision is a time-consuming process, as supervisors/advisors need considerable time to discuss with students their plans and ideas; to read their draft work; and to provide feedback, advice and suggestions both in writing and in face-to-face meetings. Yet, whilst many participants recognised an important role for taught components relating to theory and methodology, most underlined the importance of supervision as the main mechanism to support $\mathrm{PhD}$ students.

An apprenticeship model is the only successful model I know of. Supervisors need to be willing to spend the time talking extensively with students and giving detailed feedback on their work. (Professor, University of Cambridge) 
Supervisors [advisors] often need to provide detailed advice on the meanings, underlying assumptions and applications of a theory. Do not be 'hands off'. (Reader, Leeds Beckett University)

The above response captures a view that teachers and supervisors/advisors need to be wellinformed about different types of theories so that they can advise on and support student choices, without 'pushing' a particular theory or theoretical approach. Research is continually evolving, so as reflected in the response below, academic staff need to plan and structure their professional development to stay up to date.

Academic staff should make sure that they are up to date with new theories and developments in their fields. (Institute Director, University of Queensland)

Overall, survey responses relating to the role of educators stress responsibilities for educators' own self-development, for advising and supporting their students, and for upholding academic standards. However, business schools also have responsibilities to ensure that educators have the appropriate knowledge, skills, and necessary time and resources to offer students a high quality learning experience. Advice for business schools emerging from the findings is offered in the following section.

\subsection{Advice for business schools}

Several of the survey participants expressed both surprise and disappointment that many students seem to have insufficient knowledge about the nature and role of theory in research and the use of theory in their specific research area. Some participants believe that such knowledge should be gained in Master programmes. Unfortunately for doctoral educators, over the last two decades there has been a trend toward Master programmes that have little or no research training or independent research component, i.e., no dissertation, thesis or research project. As a result, many students start doctoral programmes with little, or even no previous experience in research. Some of the survey participants employed in business schools that do not have a taught component in all $\mathrm{PhD}$ programmes, advised that such courses could be highly beneficial to students.

I think students need to acquire relevant theory knowledge through a related Masters programme before undertaking a $\mathrm{PhD}$ programme. If this is not undertaken, I would recommend class attendance in a postgraduate research methodology programme as part of the knowledge acquisition process. (Professor, Swansea University)

We should strongly consider moving to a $1+3$ model, where there is a rigorous first year of research methods training, incorporating both methodological elements and theory elements. (Lecturer, University of Exeter) 
The majority of survey participants appeared to agree that $\mathrm{PhD}$ students need more support to help them learn what theory is, how it can be used, and how it can be generated. A variety of suggestions were offered with regard to the objectives and delivery of such support.

Students should have a course that includes philosophy of science and (semi-) formal logic. They should be taught explicitly how to generate interesting theories. (Professor, Yale University)

Ensure that every class in every module is anchored in theory. (Course Director, University of Cambridge)

Courses must not only teach students about theory but also how to actually use theory to inform and support their models. (Lecturer, University of Plymouth)

There should be assignments whereby each student reflects upon and evaluates papers/books within their area of research, and this should include evaluating theories. Thus, an assignment could involve evaluating at least three theories from at least three papers/books. (Professor, Royal Holloway, University of London)

Some survey participants recommended that business schools should pay more attention to the academic staff that deliver PhD programmes. Some expressed the view that teachers and supervisors/advisors need to demonstrate their own research competence by publishing in reputable journals. These publications should demonstrate the ability to effectively create and use theory. Thus, business schools might be advised to consider the publications of academic staff when making recruitment and appointment decisions. Further, given the view emerging from the data that academic staff need to stay up to date with new thoughts and findings on existing theories and the emergence of new theories, support from business schools for academic staff to participate in conferences, seminars and networking events may be considered important. In particular, business schools may need to do more to support the professional development of junior faculty and their ability to successfully supervise and guide students in the labyrinths of theory.

Not every participant in our survey agreed that students need more teaching on theory. Some individuals believe that students should learn about theory in their own personal voyage of discovery, supported by their supervisor or advisor rather than through formal taught courses. Taught courses on theory may lead students to be less creative and students may simply summarise or critique theory rather than engage with it with the aim of effectively using and developing it.

Don't teach students about theory. Let each supervisor [advisor] get on with the job. All too often, external examiners ask for chunks of philosophy and generic theory, which is not the original work of students, to be removed from the thesis. (Head of Department, University of Plymouth) 
Clearly, there exist a range of views on how to best support the learning of theory and its role in research within the context of doctoral education, ranging from formal taught inputs to nonlinear and informal social learning interactions. Whatever the mechanism, it is apparent that Business Schools must provide the necessary resources, including academic staff and learning materials. Monitoring student progression and achievement and obtaining student feedback will enable schools to evaluate the programme's performance and to identify the areas in which improvement is needed. To provide students with a high quality learning experience, participants felt that teachers and supervisors/advisors need effective support, in terms of work time, development opportunities and resources.

\section{Conclusion}

The purpose of this paper was to assess the extent and nature of theory-related teaching in $\mathrm{PhD}$ programmes, to identify what Business/Management $\mathrm{PhD}$ students should know and do in relation to theory in order to complete their programme successfully and to provide guidance to the various stakeholders in the doctoral education process (students, educators and business schools) on related aspects of doctoral education. Thus, this paper offers guidance on how theory and theoretical concepts/perspectives may be selected and used by students, and the steps that students may take to achieve the goal of making an original contribution with their research.

Our first research question was concerned with how $\mathrm{PhD}$ students learn about theory. Over two thirds of our survey participants reported that all business/management $\mathrm{PhD}$ programmes in their institution have a taught component and just under a fifth have a stand-alone course or module specifically on theory. In particular, it appears that taught courses are much more common in the UK than they were 10-15 years ago. Believing that students benefit from more structured learning, most of the UK-based survey participants support the idea of students starting PhD programmes with a taught component, as they generally do in the US.

Our second research question was concerned with what students should know and do in relation to theory in order to complete their programme satisfactorily. It is clear that students must understand research philosophy, theoretical and conceptual frameworks, methodology and research design and the relationships between them (as summarised in Table 1). Furthermore, it is important for students to appreciate how theory affects and is affected by choices of philosophy, theoretical and conceptual frameworks, methodology and research design. The participants identified a range of theories that may be suitable for inclusion in introductory crossdiscipline courses (Table 4). These suggestions provide a useful point of departure for both learners and educators.

Our third research question aimed to obtain advice for students, educators and business schools to improve the quality of students' $\mathrm{PhD}$ theses; programme completion times; and dropout rates. The results indicate that although supervisors/advisors and business schools have in recent years paid more attention to theory, there is still more that can be done. Table 5 summarises the recommendations offered to $\mathrm{PhD}$ students, educators and business schools.

\section{INSERT TABLE 5 HERE}


Although there were a range of views expressed by participants, a majority of the survey participants agreed that students need more teaching on theory and that it is the responsibility of business schools to determine the structure, content and delivery of $\mathrm{PhD}$ programmes. Schools must also provide the necessary resources, including academic staff and learning materials, to support all forms of learning, whether formal or informal. It should be noted that a few participants were not in favour of teaching specific theories to students. However, we argue that teaching need only raise students' awareness of a range of theories, with the student then responsible for following up to learn and understand the theories of relevance in greater depth. Before students select the theories that they will use in their research they must have read widely, attended courses that have involved theory in their fields, and invited suggestions from their supervisors/advisors.

The survey participants unanimously agreed that students will better understand, use and develop theory if they read widely and deeply. Therefore, educators should encourage students to read extensively and set tasks that require students to read scholarly journals. The role of toptier journals in the education of PhD students should not be underestimated. Most top-tier business/management journals only publish articles that make a theoretical contribution. The editors of these journals expect authors to make clear and distinct theoretical contributions. $\mathrm{PhD}$ students can learn how to make a theoretical contribution in their research by reading and analysing the articles published in journals such as Academy of Management Journal, Academy of Management Review, Administrative Science Quarterly, Journal of International Business Studies, Journal of Management, Journal of Management Studies, and Journal of Marketing. Several of these journals have published articles and/or editorials that provide advice and guidance to authors on how they may make a theoretical contribution in their work. Students would benefit from reading these articles and editorials, as the advice applies to $\mathrm{PhD}$ research as much as it does to research intended for publication in a scholarly journal.

Although there exists an extensive literature that examines many different aspects of pedagogy related to doctoral and research methods education, including curricula (e.g. Green, 2012), student learning (e.g. Shacham \& Od-Cohen, 2009), supervision (Lee, 2008; Whitelock, Faulkner, \& Miell, 2008) and assessment (Clarke, 2013), surprisingly there have been few studies that have considered theory use in the Business/Management $\mathrm{PhD}$, and, to our knowledge, none that attempted to discover current practice in the top business schools globally. Hence, this research fills an important gap in the literature and offers valuable insights for PhD students, educators and institutions.

This study is not without limitations. We aimed to obtain a sample that is representative of $\mathrm{PhD}$ teaching in top business schools globally, but in some regions - notably in East and South East Asia - educators did not accept our invitation to participate in the study. Several survey participants criticised us for our 'assumptions' and conceptualisation of theory. We did not assume that theory needs to be taught as a course, but this does appear to be the approach supported by the majority of our survey participants. Rather, we acknowledge that theory may be conceptualised and used in a variety of ways and that there is not one best way for students to learn about theory. The vast majority of survey participants agreed that most students struggle with certain aspects of dealing with theory, at least to some extent, and therefore that students need more and better support and guidance in selecting, using and developing theory. Because several hundred comments were provided by the participants and it was impossible for us to 
include every suggestion and reflect every opinion, we reported the most popular suggestions and viewpoints. Thus, we argue that this study provides valuable insights into how theory is taught and learnt about by students, and that it generated useful sets of recommendations for students, educators and business schools.

\section{References}

Austin, A. E. (2002). Preparing the next generation of faculty: graduate school as socialization to the academic career. Journal of Higher Education, 73(1), 94-122.

Ajzen, I. (1991). The theory of planned behavior. Organizational Behavior and Human Decision Processes, 50(2), 179-211.

Bell, E., Bryman, A., \& Harley, B. (2018). Business research methods, $5^{\text {th }}$ edition. Oxford: Oxford University Press.

Braun, V., \& Clarke, V. (2012). Thematic analysis. In H. Cooper, P. M. Camic, D. L. Long, A. T. Panter, D. Rindskopf, \& K. J. Sher (Eds.), APA Handbook of Research Methods in Psychology, Vol. 2. Research Designs: Quantitative, Qualitative, Neuropsychological, and Biological (pp. 57-71). Washington, DC: American Psychological Association.

Byron, K., \& Thatcher, S. M. B. (2016). Editors' comments: "What I know now that I wish I knew then" - Teaching theory and theory building. Academy of Management Review, 41(1), $1-8$.

Clarke, G. (2013). Developments in doctoral assessment in the UK. In M. Kompf, \& P. M. Denicolo (Eds.), Critical issues in higher education (pp. 23-36). Rotterdam: Sense Publishers.

Clarke, G., \& Lunt, I. (2014). The concept of 'originality' in the PhD: how is it interpreted by examiners? Assessment \& Evaluation in Higher Education, 39(7), 803-820.

Corley, K. G., \& Gioia, D A. (2011). Building theory about theory building: what constitutes a theoretical contribution? Academy of Management Review, 36(1), 12-32.

Creswell, J. W., \& Creswell, J. D. (2018). Research design: qualitative, quantitative, and mixed methods approaches, fifth edition. Thousand Oaks, CA: Sage.

Denzin, N. K., \& Lincoln, Y. S. (2005). The SAGE handbook of qualitative research, third edition. Thousand Oaks, CA: Sage.

Eisenhardt, K. M. (1989). Building theories from case study research. Academy of Management Review, 14(4), 532-550.

Eisenhardt, K. M. \& Graebner, M. E. (2007). Theory building from cases: opportunities and challenges. Academy of Management Review, 50(1), 25-32.

Enders, J. (2002). Serving many masters: the PhD on the labour market, the everlasting need of inequality, and the premature death of Humboldt. Higher Education, 44, 3-4, 493-517.

Flick, U. (2014). An introduction to qualitative research, fifth edition. London: SAGE.

Geven, K., Skopek, J., \& Triventi, M. (2018). How to increase PhD completion rates? An impact evaluation of two reforms in a selective graduate school, 1976-2012. Research in Higher Education, 59(5), 529-552.

Giddens, A. (1984). The constitution of society: outline of the theory of structuration. Berkeley, CA: University of California Press. 
Grant, R. M. (1996). Toward a knowledge-based theory of the firm. Strategic Management Journal, 17(winter special issue), 109-122.

Green, B. (2012). Addressing the curriculum problem in doctoral education. Australian Universities' Review, 54(1), 10-18.

Hunt, S. D. (1983). Marketing theory: the philosophy of marketing science. Homewood, Ill.: R. D. Irwin.

Iqbal, J. (2007). Learning from a doctoral research project: structure and content of a research proposal. The Electronic Journal of Business Research Methods, 5(1), 11-20.

Jabareen, Y. (2009). Building a conceptual framework: philosophy, definitions, and procedure. International Journal of Qualitative Methods, 8(4), 49-62.

Joas, H., \& Knobl, W. (2009). Social theory: twenty introductory lectures. Cambridge: Cambridge University Press.

Jump, P. (2013). PhD completion rates, 2013. Times Higher Education, July $26^{\text {th }}$. https://www.timeshighereducation.com/news/phd-completion-rates-2013/2006040.article. Accessed 12 August 2018.

Kember, D. (1997). A reconceptualisation of the research into university academics' conceptions of teaching. Learning and Instruction, 7, 225-275.

Kyvik, S., \& Olsen, T. B. (2014). Increasing completion rates in Norwegian doctoral training: multiple causes for efficiency improvements. Studies in Higher Education, 39(9), 1668-1682.

Lean, J. (2012). Preparing for an uncertain future: the enterprising PhD student. Journal of Small Business and Enterprise Development, 19(3), 532-548.

Lee, A. (2008). How are doctoral students supervised? Concepts of doctoral research supervision. Studies in Higher Education, 33(3), 267-281.

Lee, N., \& Lings, I. (2008). Doing business research: a guide to theory and practice. London: Sage.

Lin, A. C. (1998). Bridging positivist and interpretivist approaches to qualitative methods. Policy Studies Journal, 26(1), 162-180.

Lings, I. (2008). Theory, conceptualisation and hypotheses. In N. Lee, \& I. Lings, Doing business research: a guide to theory and practice (pp. 107-133). London: Sage.

Litalien, D., \& Guay, F. (2015). Dropout intentions in PhD studies: a comprehensive model based on interpersonal relationships and motivational resources. Contemporary Educational Psychology, 41, April, 218-231.

McFayden, M. A., \& Cannella, A. A. (2004). Social capital and knowledge creation: diminishing returns of the number and strength of exchange relationships. Academy of Management Journal, 47(5), 735-746.

Meek, V. L., Teichler, U., \& Kearney, M. L. (2009). Higher education, research and innovation: changing dynamics. Kassel: International Centre for Higher Education Research (INCHERKassel).

Mowbray, S., \& Halse, C. (2010). The purpose of the PhD: theorising the skills acquired by students. Higher Education Research \& Development, 29(6), 653-664.

Newbery, R., Lean, J., \& Moizer, J. (2016). Evaluating the impact of serious games: the effect of gaming on entrepreneurial intent. Information Technology \& People, 29(4), 733-749.

Nyquist, J. D. (2002). The PhD a tapestry of change for the 21st century. Change: The Magazine of Higher Learning, 34(6), 12-20. 
O'Connor, B. N. (2011). Perspectives on professional doctorate education in the United States. Work Based Learning e-Journal, 2(1), 44-64.

Park, C. (2005). New variant PhD: the changing nature of the doctorate in the UK. Journal of Higher Education Policy and Management, 27(2), 189-207.

Phillips, E. M., \& Pugh, D. S. (2015). How to get a PhD: a handbook for students and their supervisors. Maidenhead: Open University Press/McGraw-Hill.

Popper, K. (2002). The logic of scientific discovery. Abingdon: Routledge.

Prøitz, T. S., \& Wittek, L. (2019). New directions in doctoral programmes: bridging tensions between theory and practice? Teaching in Higher Education, published online February $7^{\text {th }}$, 2019.

Saunders, M., Gray, D., Tosey, P., \& Sadler-Smith, E. (2015). Concepts and theory building. In L. Anderson, J. Gold, J. Stewart, \& R. Thorpe (Eds.), A guide to professional doctorates in business and management (pp. 35-56). London: Sage.

Saunders, B., Sim, J., Kingstone, T., Baker, S., Waterfield, J., Bartlam, B., Burroughs, H., \& Jinks, C. (2018). Saturation in qualitative research: exploring its conceptualization and operationalization. Quality \& Quantity, 52(4), 1893-1907.

Shacham, M., \& Od-Cohen, Y. (2009). Rethinking PhD learning incorporating communities of practice. Innovations in Education and Teaching International, 46(3), 279-292.

Simons, M., \& Elen, J. (2007). The 'research-teaching nexus' and 'education through research': an exploration of ambivalences. Studies in Higher Education, 32(5), 617-631.

Spronken-Smith, R., Cameron, C., \& Quigg, R. (2018). Factors contributing to high PhD completion rates: a case study in a research-intensive university in New Zealand. Assessment \& Evaluation in Higher Education, 43(1), 94-109.

Van de Ven, A. H. (1989). Nothing is quite so practical as a good theory. Academy of Management Review, 14(4), 486-489.

Vygotsky, L. S. (1978). Mind in society: The development of higher psychological processes. Cambridge, MA: Harvard University Press.

Wellington, J. (2013). Searching for 'doctorateness'. Studies in Higher Education, 38(10), 14901503.

Whetten, D. (1989). What constitutes a theoretical contribution? Academy of Management Review, 14(4), 490-495.

Whitelock, D., Faulkner, D., \& Miell, D. (2008). Promoting creativity in PhD supervision: tensions and dilemmas. Thinking Skills and Creativity, 3(2), 143-153. 


\section{Theory}

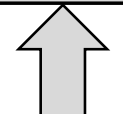

Inductive research

Observing cases in the real world and then constructing a theory to cover all cases

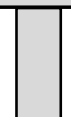

Deductive research Starting with a theory and then using it to explain observations in the real world

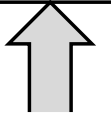

Abductive research

Generalising from interactions between theory and real world observations

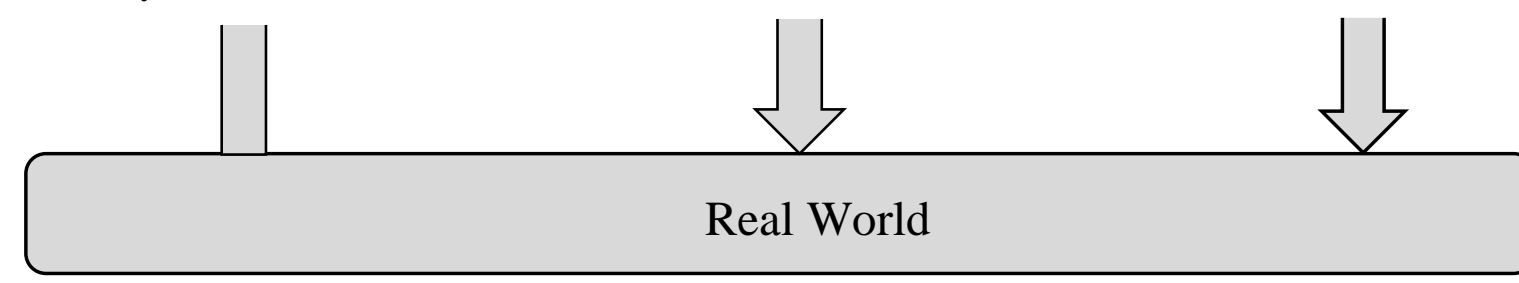

Fig. 1. The role of theory in inductive, deductive and abductive research. 
Use-Case Example: Theory of Planned Behaviour

Many researchers have used Ajzen's (1991) 'Theory of Planned Behaviour' (TPB), developed in the field of psychology, as a theoretical framework for studies aiming to explain the behaviours of individuals. Applications of the theory can be found across a wide range of topics, with researchers seeking to explain behaviours as diverse as alcohol consumption, political participation and food waste reduction. In the field of management education, TPB has been used as a theoretical framework underpinning studies exploring the factors affecting the entrepreneurial intentions of higher education students. For instance, Newbery et al. (2016) use Ajzen's theory to develop a conceptual framework that represents the key concepts and relationships associated with their study examining the effect of participation in an entrepreneurship simulation game on the entrepreneurial intentions of undergraduate students. By developing a conceptual framework that situates Ajzen's theory within a specific research context, they are able to demonstrate a sound theoretical underpinning for their study and make a contribution to existing theory from their research results.

Fig. 2. Theoretical and conceptual frameworks - A use-case example. 


\section{Table 1}

Research philosophy, theoretical and conceptual frameworks, methodology and research design (emphasising the contrasting stances).

\begin{tabular}{|c|c|c|}
\hline $\begin{array}{l}\text { Research } \\
\text { Philosophy }\end{array}$ & $\begin{array}{l}\text { Ontology } \\
\text { The nature of reality or being }\end{array}$ & $\begin{array}{l}\text { Epistemology } \\
\text { What constitutes acceptable knowledge }\end{array}$ \\
\hline Positivism & $\begin{array}{l}\text { There is one single reality; it is external } \\
\text { and independent }\end{array}$ & $\begin{array}{l}\text { Reality can be observed and measured } \\
\text { using scientific methods }\end{array}$ \\
\hline Critical Realism & $\begin{array}{l}\text { Reality exists externally but is layered, } \\
\text { experienced indirectly and affected by } \\
\text { perceptions }\end{array}$ & $\begin{array}{l}\text { Reality is historically situated and } \\
\text { socially constructed; a range of } \\
\text { methods can be used to build causal } \\
\text { explanations }\end{array}$ \\
\hline Interpretivism & $\begin{array}{l}\text { Reality is complex - there is no single } \\
\text { reality; it is socially constructed }\end{array}$ & $\begin{array}{l}\text { Reality is interpreted to reveal } \\
\text { underlying meaning; it can't be reduced } \\
\text { to measurable observations }\end{array}$ \\
\hline Post-Modernism & $\begin{array}{l}\text { Reality is socially constructed through } \\
\text { power relations }\end{array}$ & $\begin{array}{l}\text { Reality defined by dominant powers; } \\
\text { focus on revealing repressed } \\
\text { interpretations }\end{array}$ \\
\hline Pragmatism & $\begin{array}{l}\text { Reality is interpreted in terms of its } \\
\text { usefulness in practical situations and } \\
\text { for taking action }\end{array}$ & $\begin{array}{l}\text { The focus is on actions and solutions; } \\
\text { useful knowledge is that which support } \\
\text { successful action }\end{array}$ \\
\hline $\begin{array}{l}\text { Theoretical and } \\
\text { Conceptual } \\
\text { Frameworks }\end{array}$ & $\begin{array}{l}\text { Theoretical framework } \\
\text { The theoretical framework or model } \\
\text { specifies the theory that is used to guide } \\
\text { the research, i.e., the theory used to } \\
\text { offer explanations for particular } \\
\text { phenomena or research problems. }\end{array}$ & $\begin{array}{l}\text { Conceptual framework } \\
\text { The conceptual framework/model is the } \\
\text { researcher's conceptualisation of the } \\
\text { constructs or concepts of interest and } \\
\text { the proposed relationships between } \\
\text { them. }\end{array}$ \\
\hline $\begin{array}{l}\text { Methodology } \\
\text { (based on the } \\
\text { ontological and } \\
\text { epistemological } \\
\text { assumptions) }\end{array}$ & $\begin{array}{l}\text { Quantitative } \\
\text { Objectivist } \\
\text { Positivist } \\
\text { Empiricist } \\
\text { Nomothetic }\end{array}$ & $\begin{array}{l}\text { Qualitative } \\
\text { Constructionist } \\
\text { Interpretivist } \\
\text { Hermeneutic }\end{array}$ \\
\hline $\begin{array}{l}\text { Research } \\
\text { Design } \\
\text { (must align with } \\
\text { chosen methodology) }\end{array}$ & $\begin{array}{l}\text { Deductive reasoning } \\
\text { Surveys } \\
\text { Experiments }\end{array}$ & $\begin{array}{l}\text { Inductive reasoning } \\
\text { Interviews } \\
\text { Action research } \\
\text { Case studies } \\
\text { Ethnography }\end{array}$ \\
\hline
\end{tabular}

Source: Developed by authors with reference to O'Gorman and MacIntosh (2015); Saunders et al. (2015); and Twining et al. (2017). 
Table 2

Profile of survey participants.

\begin{tabular}{llrr}
\hline & & $\begin{array}{c}\text { Number of } \\
\text { participants }\end{array}$ & $\begin{array}{r}\text { Per cent } \\
\text { of sample }\end{array}$ \\
\hline Country in which & Australia & 4 & $6.5 \%$ \\
working & United Kingdom & 37 & $59.6 \%$ \\
& United States $^{\text {Other }}{ }^{\text {J }}$ & 17 & $27.4 \%$ \\
& & 4 & $6.5 \%$ \\
& Management/leadership & & \\
& Full professor & 8 & $13.0 \%$ \\
& Reader & 31 & $50.0 \%$ \\
Associate professor & 3 & $4.8 \%$ \\
& Senior lecturer & 9 & $14.5 \%$ \\
& Lecturer & 5 & $8.0 \%$ \\
& Economics & 6 & $9.7 \%$ \\
& Entrepreneurship & & \\
& Information Management/Systems & 6 & $9.7 \%$ \\
& International Business/Management & 8 & $13.0 \%$ \\
& Management & 9 & $14.5 \%$ \\
& Marketing & 6 & $9.7 \%$ \\
& Operations Management & 13 & $21.0 \%$ \\
& Organisational Behaviour & 11 & $17.7 \%$ \\
Strategy & 6 & $9.7 \%$ \\
& Other & 9 & $14.5 \%$ \\
& & 10 & $16.1 \%$ \\
& & 13 & $21.0 \%$ \\
\hline
\end{tabular}

${ }^{\mathrm{a} O t h e r ~ c o u n t r i e s ~ w e r e ~ C a n a d a ~(1), ~ F r a n c e ~(1) ~ a n d ~ S w e d e n ~(2) ~}$

${ }^{\mathrm{b}}$ Several participants named two or more disciplines, hence the percentages total more than 100

${ }^{c}$ Other disciplines included Accounting; Business Ethics, Governance and Corporate Social Responsibility; Finance; Human Resource Management; Logistics; and Operations Research 
Table 3

Data structure showing sample concepts, themes and aggregate dimensions.

\begin{tabular}{|c|c|c|}
\hline Concepts & Themes & $\begin{array}{c}\text { Aggregate } \\
\text { Dimensions }\end{array}$ \\
\hline $\begin{array}{l}\text { - Reading widely in field, particularly top-tier journals } \\
\text { - Reading about theory in research methodology books } \\
\text { - Reading about theory in other disciplines }\end{array}$ & Reading & \multirow{4}{*}{$\begin{array}{l}\text { Advice } \\
\text { for } \\
\text { PhD Students }\end{array}$} \\
\hline $\begin{array}{l}\text { - Seeking advice on theories from supervisors/advisors } \\
\text { - Obtaining formative feedback from supervisors/advisors }\end{array}$ & $\begin{array}{l}\text { Interacting with } \\
\text { supervisors/ advisors }\end{array}$ & \\
\hline $\begin{array}{l}\text { - Considering all options before selecting which theories to } \\
\text { use } \\
\text { - Ensuring that intended theoretical contributions are } \\
\text { specified at the start of the research process }\end{array}$ & Planning & \\
\hline $\begin{array}{l}\text { - Attending and participating in conferences, seminars and } \\
\text { network events } \\
\text { - Writing for scholarly journals }\end{array}$ & Scholarly activities & \\
\hline $\begin{array}{l}\text { - Encouraging students to read widely in their fields, } \\
\text { particularly the top-tier journals } \\
\text { - Encouraging students to read about theory in research } \\
\text { methodology books } \\
\text { - Encouraging students to read about theory in other } \\
\text { disciplines }\end{array}$ & Reading & \multirow{3}{*}{$\begin{array}{l}\text { Advice } \\
\text { for } \\
\text { Educators }\end{array}$} \\
\hline $\begin{array}{l}\text { - Giving students tasks that force them to engage with } \\
\text { theory } \\
\text { - Having regular face-to-face meetings with students } \\
\text { - Providing on-going formative feedback }\end{array}$ & Interacting with students & \\
\hline $\begin{array}{l}\text { - Staying up to date through regular reading } \\
\text { - Staying up to date by regularly participating in } \\
\text { conferences, seminars and network events }\end{array}$ & Self-development & \\
\hline $\begin{array}{l}\text { - Not leaving it to students to independently learn about } \\
\text { theory } \\
\text { - Planning where, when and how students learn about } \\
\text { theory }\end{array}$ & $\begin{array}{l}\text { Providing a structured } \\
\text { learning experience for } \\
\text { students }\end{array}$ & \multirow{3}{*}{$\begin{array}{l}\text { Advice } \\
\text { for } \\
\text { Business } \\
\text { Schools }\end{array}$} \\
\hline $\begin{array}{l}\text { - Appointing academic staff that have demonstrated the } \\
\text { ability to publish in top-tier journals } \\
\text { - Supporting staff participation in conferences, seminars } \\
\text { and network events }\end{array}$ & $\begin{array}{l}\text { Academic staff selection } \\
\text { and development }\end{array}$ & \\
\hline - Allocating sufficient time for supervision duties & $\begin{array}{l}\text { Academic staff working } \\
\text { conditions }\end{array}$ & \\
\hline
\end{tabular}




\section{Table 4}

Theories that may be suitable for teaching to all business management $\mathrm{PhD}$ students.

Name of theory/theoretical concept

Percentage of survey participants who recommended the theory/theoretical concept

\begin{tabular}{ll} 
Critical theory & $61.9 \%$ \\
Agency theory & $60.9 \%$ \\
Organisational theory & $56.5 \%$ \\
Behavioural decision theory & $52.1 \%$ \\
Resource based view & $51.0 \%$ \\
General economic theories, e.g. micro, macro & $46.5 \%$ \\
Institutional theory & $45.8 \%$ \\
Social construction theory & $45.0 \%$ \\
Interpretative theory & $44.4 \%$ \\
Stakeholder theory & $43.6 \%$ \\
Network theory & $43.5 \%$ \\
\hline
\end{tabular}


Table 5

Recommendations for $\mathrm{PhD}$ students, educators and business schools.

\begin{tabular}{|c|c|}
\hline & Recommendations \\
\hline PhD students & $\begin{array}{l}\text { - Recognise that theory is essential in all PhD research } \\
\text { - Read widely in your field, particularly the top-tier journals } \\
\text { - Read about theory in research methodology books } \\
\text { - Seek advice on theories from your supervisor/advisor } \\
\text { - Don't rush into selecting theories until you have properly } \\
\text { considered all possible options, including theories from other } \\
\text { disciplines } \\
\text { - Develop an understanding of quantitative research techniques/data } \\
\text { - } \text { analysis so that you can interpret all published research } \\
\text { - } \text { research before you start writing anything } \\
\text { - Publish in a refereed journal before you submit your PhD } \\
\text { thesis/dissertation }\end{array}$ \\
\hline Educators & $\begin{array}{l}\text { - Don't make assumptions about students' understanding of theory } \\
\text { - Encourage students to read widely in their fields, particularly the } \\
\text { top-tier journals } \\
\text { - Encourage students to read about theory in research methodology } \\
\text { books } \\
\text { - Give students tasks, e.g. writing literature reviews, that force them } \\
\text { to read about and engage with theory } \\
\text { - Have regular face-to-face meetings with students (at least every 4-6 } \\
\text { weeks) } \\
\text { - Provide detailed feedback on draft work given to you by students } \\
\text { - Stay up to date yourself by reading regularly and widely in your } \\
\text { field and by regularly participating in conferences, seminars and } \\
\text { network events }\end{array}$ \\
\hline Business Schools & $\begin{array}{l}\text { - Don't leave it to students to independently learn about theory } \\
\text { - Plan where, when and how students will learn about theory } \\
\text { - Ensure that applicants to PhD programmes have completed a } \\
\text { Master degree with a research training and independent research } \\
\text { component; if the student has not completed such a programme, } \\
\text { make it mandatory for them to complete a postgraduate research } \\
\text { methodology course, possibly in the } 1+3 \text { format } \\
\text { - Recruit/appoint academic staff that have demonstrated the ability to } \\
\text { publish in top-tier journals } \\
\text { - Ensure that workload models give PhD teachers/supervisors/ } \\
\text { advisors sufficient time to meet with students and read their work } \\
\text { - Ensure that academic staff stay up to date in their fields and support } \\
\text { them for participation in conferences, seminars and networking } \\
\text { events }\end{array}$ \\
\hline
\end{tabular}


